\title{
MATERNAL AND PATERNAL EFFECT ON THE CHARACTERS OF DURIAN (Durio zibethinus Murr.) FRUIT FROM CROSS-POLLINATION
}

\author{
Ni Luh Putu Indriyani, Sri Hadiati, Fitriana Nasution, \\ Edison, Sudjijo and Yulia Irawati \\ Indonesian Agency of Agricultural Research and Development \\ Indonesian Tropical Fruit Research Institute, Jl. Raya Solok-Aripan, Km 8. Solok \\ West Sumatera, INDONESIA \\ e-mail: nlp_indriyani@yahoo.co.id
}

(Received March 28, 2012/Accepted September 25, 2012)

\section{A B S T R A C T}

The aim of the research was to study the influence of maternal and paternal parents on the characters of durian fruit resulted from their crossing. The parents used in the crossings were Matahari, Kani, Otong, Sitokong, Lai, Kim, Sunan, Bokor, Hortimart and Tangkue. The results showed that the percentage of fruit set of their crossing ranged between $0 \%$ and 20\%. Maternal effect was significant on the characters of fruit set, fruit weight, fruit circumference, fruit length, fruit rind thickness, flesh thickness, edible portion, spine length, the number of locules without the pulp, seed weight per fruit, seed number per fruit, and percentage of deflated seed. The use of Matahari variety as maternal parent produced the largest fruit with the thickest flesh, the highest percentage of edible portion and all locules were filled. Paternal effect occurs on fruit set, fruit length, rind thickness, seed number per fruit, seed weight per fruit, and percentage of deflated seed. The use of Sitokong variety as paternal parent resulted the lowest seed weight per fruit, seeds number per fruit and the highest percentage of deflated seed.

Key words: maternal parent, paternal parent, xenia, metaxenia, fruit quality

\section{INTRODUCTION}

The durian (Durio zibethinus Murr.) is an open-pollinated species, so naturally there is always cross- pollination among the varieties. In Asia, most commercial cultivars of durian are selected from seeds produced by open pollination, and subsequently propagated vegetatively (Lim and Luders, 2009). 
The durian shows selfincompatibility (Shaari et al., 1985; Lim and Luders, 1998; Bumrungsri et al., 2009). Cross-pollination on D24 cultivar produces fruit set of 54-60\%, while the self-pollination produced fruit set only < 5\% (George et al., 1993 cit. Lim and Luders, 2009). Lo et al. (2007) stated that 35 days after pollination, self-pollination on Chanee does not produce any fruit set, while the percentage of fruit set on Monthong is $6.9 \%$ to $23.6 \%$. Crosspollination produces a significantly higher fruit set than self-pollination. Similar trials by Lim and Luders (2009) also showed that selfpollination on Chanee, Monthong and Luang varieties of durian failed to produce fruit. Honsho et al. (2004) stated that cross-pollination produced a higher fruit set than self-pollination indicating a self-incompatibility within the species.

Self-incompatibility properties on durian cause the need for crosspollination to ensure the fertilization successful. Cross-pollination needs maternal and paternal parents from different varieties or species. Selection of varieties or species combinations which planted should take into consideration various aspects, one of which is the influence of maternal and paternal parent on fruit characteristics. Genes of the paternal parent (pollen) can influence fruit characteristics or seeds. Denney (1992) cit. Mizrahi et al. (2004) states in more detail that the effect of pollen on tissue which contains at least one set of genes from the male, namely the embryo and the endosperm, is called xenia, while the effect of pollen on fruit tissue of maternal parent, such as the pericarp and other fruit components that have no male contribution, is called metaxenia. Metaxenia can be used to identify the best male parent to accelerate the period of fruit development and improve the yield in mixed cultivar plantings (Olfati et al., 2010).

Some results of maternal and paternal parent effect have been reported. In the crossing of dragon fruit plants, the paternal parent affected fruit weight, harvest time, the percentage of fruit flesh, skin and flesh dry weight of fruit, number of seeds per fruit and sugar content, but it did not affect total content of soluble solids or acidity (Mizrahi et al., 2004). Crossing 'Rabbiteye' blueberry (Vaccinium ashei Reade) and $V$. corymbosum L. produced a lower percentage of fruit set, number of seeds per fruit, fruit weight, and increased fruit development period (harvest time) when compared with crossings between 'Rabbiteye' blueberry varieties. Crossing V. corymbosum L. with 'Rabbiteye' blueberry results in the same percentage of fruit set and length of the fruit development period, but reduces the number of seeds per fruit and fruit weight compared with pollination between the varieties of $V$. corymbosum $\mathrm{L}$. Self-pollination in $V$. corymbosum L. significantly decreases the number of seeds per fruit and fruit weight, and increases fruit development period (Gupton and Spiers, 1994).

The aim of the research was to study the influence of maternal and 
paternal parents on the characters of durian fruit from their crossing.

\section{MATERIAL AND METHODS}

The research was conducted at Subang Experimental Station of Indonesian Tropical Fruit Research Institute (ITFRI) from January 2010 until December 2011. The materials used in cross-pollination were several varieties of durian trees as maternal and paternal parents, and they were also used reciprocal in crossing. The parents used in the crossing were Matahari, Kani, Otong, Sitokong, Lai, Kim, Sunan, Bokor, Hortimart and Tangkue.

The durian trees which were used in the crossing combinations were about 15 years old. The crossing was carried out at the time between 7 to 9 p.m. Emasculation was performed on the flowers of the maternal parent which were expected to bloom in the evening. These flowers were isolated by using a paper bag after emasculation which done in the morning or late af- ternoon. Flowers of the paternal parent that would bloom were taken in the afternoon and placed upside down in a container covered with wet tissue or cotton. The flowers were dried about 1 hour in order to accelerate the bursting of anthers. Cross-pollination was carried out at night when the pollen was released from the anther. Pollinated flowers were re-isolated with a paper bag and labelled. The label contained information about the maternal and paternal parents that were used and the date of crossing.

The variables observed included the percentage of fruit set and some characters of the fruit from the crossings (fruit circumference, fruit length, rind thickness, flesh thickness, edible portion, spine length, number of locules per fruit, number of locules without pulp unit, seeds number per fruit, seed weight per fruit, and percentage of deflated seed). Fruit characters observation was done after harvest. The percentage of fruit set, edible portion, and percentage of deflated seed were calculated using the formula:

$$
\begin{aligned}
& \begin{array}{c}
\text { Percentage of fruit set }(\%)=\frac{\text { umber of fruit harvested }}{\text { number of flowers cross-pollinated }} \\
\text { num } 100 \%
\end{array} \\
& \begin{array}{c}
\text { Edible portion }(\%)=\frac{\text { fruit weight }- \text { rind weight }- \text { seed weight }}{\text { fruit weight }} \\
\text { - }
\end{array}
\end{aligned}
$$

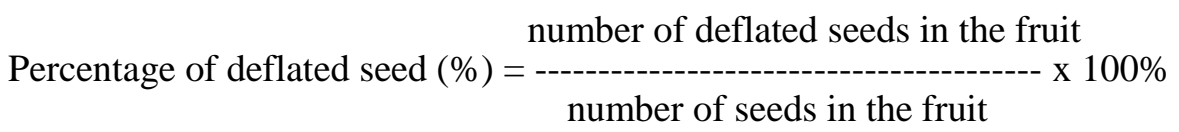


The number of fruit sampled ranged from 1 to 7 , depending on the number of fruit harvested. The data were analysed descriptively. Student t-test was used to determine the effects of maternal and paternal parents. Correlation analysis was done to determine the relationship between the number of flowers that had been cross-pollinated and the percentage of fruit set.

\section{RESULTS AND DISCUSSION}

The percentage of fruit set for the various crossing combinations was 0 to $20 \%$ (Tab. 1). Of the 26 crossing combinations, half of them did not produce fruit, which were: Matahari x Kani, Sitokong x Otong, Sitokong $\mathrm{x}$ Matahari, Sitokong $\mathrm{x}$ Lai, Lai $\mathrm{x}$ Kani, Lai x Sunan, Kani x Sitokong, Kani x Matahari, Kim x Tangkue, Sunan x Kim, Sunan x Lai, Otong x Matahari and Otong $x$ Lai. The crossing that produced the highest fruit set was Matahari x Sitokong. There were various factors that cause a low percentage of fruit set, such as low pollen viability, pollination failure, fertilization failure, self-incompatibility, clonal incompatibility, low level of nutrients, insufficient water, damage to flowers and fruit due to pests and diseases, and adverse weather conditions during flowering and fruit development (Lim and Luders, 2009). There was no correlation between the number of cross-pollinated flowers and the percentage of fruit set $(r=0.12)$.

Table 2 showed that the maternal and paternal parents significantly influenced the percentage of fruit set.
This means that the using of different maternal and paternal parents would produce a different percentage of fruit set. The maternal parent that produced the highest percentage of fruit set was Kim variety, but no significant differences were observed among Kim, Kani, Lai and Matahari varieties. The paternal parents that produced the highest percentage of fruit set were Kim, Otong, Sunan and Sitokong varieties. Similar results were obtained when crossing cherimoya, where the paternal parent affected the percentage of fruit set (Kahn et al., 2003).

Table 3 presented fruit performance in the crossing combinations of durian varieties. Visually, the flesh colour of Lai x Sitokong, Lai x Matahari and Lai $x$ Otong were the same, i.e. orange. There was no difference in flesh colour between these crossings and open-pollinated of Lai. Similarly with Matahari, Kani and Sitokong varieties as maternal parents. This suggested that the paternal parents did not affect the flesh colour of their crossing. In other words, this means that the flesh colour was determined by the maternal parent. Furthermore, Table 3 was used to calculate the influence of maternal and paternal parents on the characteristics of durian fruit in the crossing combinations (Tabs 4 and 5).

Table 4 showed that the maternal parent significantly affected almost all of the measured characters of fruit, which included fruit weight, fruit circumference, fruit length, rind thickness, flesh thickness, edible portion, spine length, number of locules without pulp unit, seed 
Table 1. Percentage of fruit set for various crossing combinations of durian

\begin{tabular}{|l|l|c|c|c|}
\hline \multicolumn{2}{|l|}{ Crossing combination } & $\begin{array}{c}\text { Number of cross- } \\
\text { pollinated flowers }\end{array}$ & $\begin{array}{c}\text { Number of } \\
\text { fruit harvested }\end{array}$ & $\begin{array}{c}\text { Fruit set percent- } \\
\text { age } \\
{[\%]}\end{array}$ \\
\hline 1 & Matahari x Kani & 31 & 0 & 0 \\
\hline 2 & Matahari x Otong & 35 & 1 & 2.86 \\
\hline 3 & Matahari x Sitokong & 15 & 3 & 20.00 \\
\hline 4 & Matahari x Lai & 30 & 2 & 6.67 \\
\hline 5 & Sitokong x Kani & 49 & 1 & 2.04 \\
\hline 6 & Sitokong x Otong & 34 & 0 & 0.00 \\
\hline 7 & Sitokong x Matahari & 25 & 0 & 0.00 \\
\hline 8 & Sitokong x Lai & 26 & 0 & 0.00 \\
\hline 9 & Lai x Kani & 41 & 0 & 0.00 \\
\hline 10 & Lai x Otong & 37 & 2 & 5.41 \\
\hline 11 & Lai x Sitokong & 52 & 1 & 1.92 \\
\hline 12 & Lai x Sunan & 10 & 0 & 0.00 \\
\hline 13 & Lai x Matahari & 100 & 9 & 9.00 \\
\hline 14 & Kani x Sitokong & 35 & 0 & 0.00 \\
\hline 15 & Kani x Matahari & 17 & 0 & 0.00 \\
\hline 16 & Kani x Otong & 28 & 4 & 14.29 \\
\hline 17 & Kani x Lai & 21 & 1 & 4.76 \\
\hline 18 & Bokor x Kim & 25 & 2 & 8.00 \\
\hline 19 & Kim x Bokor & 40 & 4 & 10.00 \\
\hline 20 & Kim x Tangkue & 15 & 0 & 0.00 \\
\hline 21 & Kim x Sunan & 20 & 3 & 15.00 \\
\hline 22 & Sunan x Kim & 30 & 0 & 0.00 \\
\hline 23 & Sunan x Lai & 15 & 0 & 0.00 \\
\hline 24 & Otong x Matahari & 3 & 0 & 0.00 \\
\hline 25 & Otong x Lai & 72 & 0.00 \\
\hline 26 & Hortimart x Tangkue & 75 & 5.33 \\
\hline & & & 0 & \\
\hline
\end{tabular}

The data in Table 1 was further used to calculate the influence of maternal and paternal parents on the percentage of fruit set as presented in Table 2

Table 2. The effect of maternal and paternal parents on the percentage of durian fruit set. Data were transformed by $\sqrt{ }(x+0.5)$

\begin{tabular}{|l|l|c|c|}
\hline No. & Variety & Maternal parent & Paternal parent \\
\hline 1 & Otong & $0.00 \mathrm{a}^{*}$ & $5.64 \mathrm{~b}^{*}$ \\
\hline 2 & Sunan & $0.00 \mathrm{a}$ & $7.50 \mathrm{~b}$ \\
\hline 3 & Sitokong & $0.51 \mathrm{a}$ & $7.31 \mathrm{~b}$ \\
\hline 4 & Kani & $4.76 \mathrm{ab}$ & $0.68 \mathrm{a}$ \\
\hline 5 & Lai & $3.27 \mathrm{ab}$ & $2.29 \mathrm{ab}$ \\
\hline 6 & Kim & $8.33 \mathrm{~b}$ & $4.00 \mathrm{~b}$ \\
\hline 7 & Matahari & $7.38 \mathrm{ab}$ & $2.25 \mathrm{ab}$ \\
\hline 8 & Tangkue & - & $2.67 \mathrm{ab}$ \\
\hline
\end{tabular}

*Means in columns followed by the same letter are not significantly different according to Student t-test at $5 \%$ level of significance 
N.L.P. Indriyani et al.

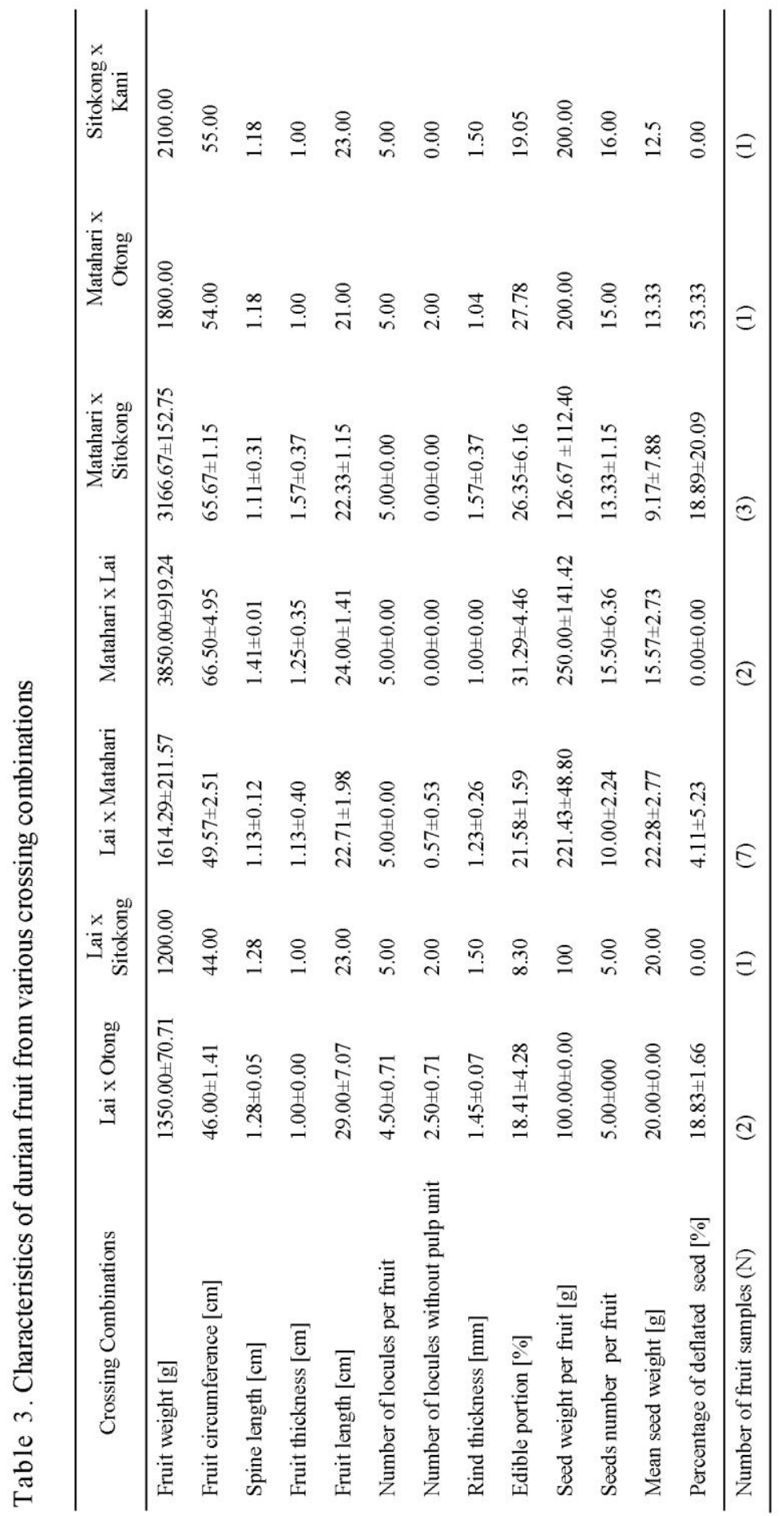


Maternal and paternal effect.....

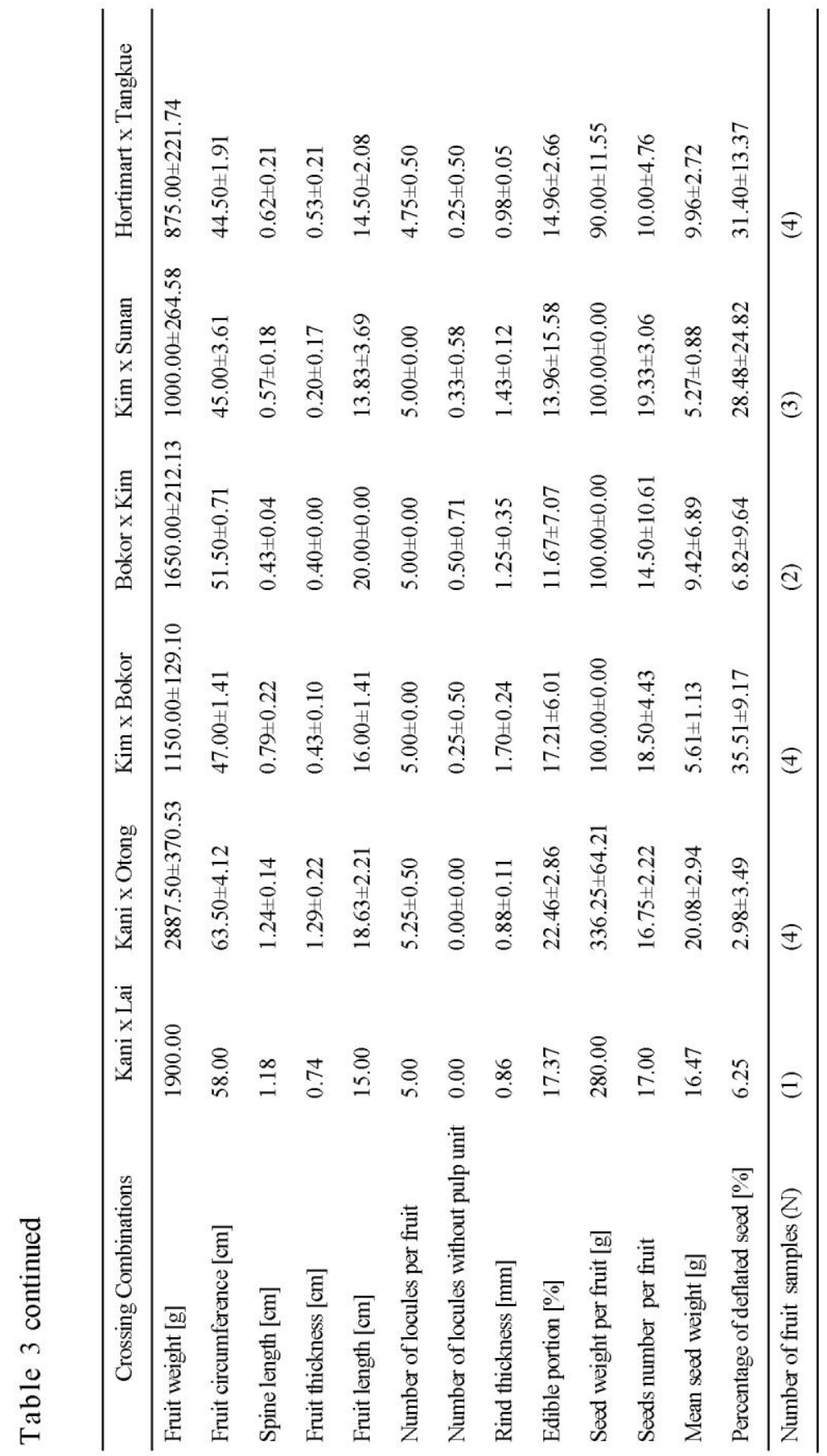


N.L.P. Indriyani et al.

\begin{tabular}{|c|c|c|c|c|}
\hline 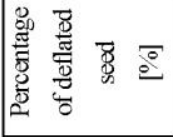 & 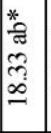 & 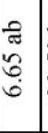 & & 孚 \\
\hline 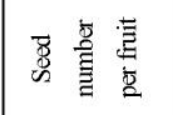 & 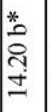 & 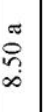 & & $\begin{array}{l}0 \\
0 \\
0 \\
0 \\
0 \\
0 \\
0\end{array}$ \\
\hline 总总 & 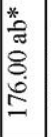 & 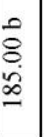 & & 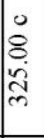 \\
\hline 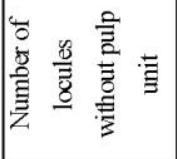 & $\begin{array}{l}* \\
\tilde{c} \\
\tilde{8} \\
0 \\
0\end{array}$ & 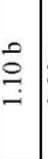 & & 范 \\
\hline 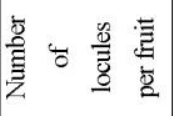 & 足 & 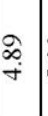 & & ڤิ \\
\hline 善暿 & * & $\begin{array}{l}\stackrel{0}{\infty} \\
\stackrel{\infty}{\square} \\
=\end{array}$ & 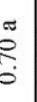 & 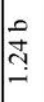 \\
\hline 递总 & 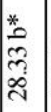 & 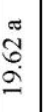 & 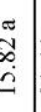 & 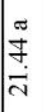 \\
\hline 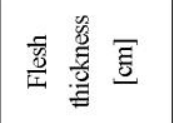 & 落 & $\stackrel{0}{\rightleftarrows}$ & हैं & $\stackrel{\infty}{\infty}$ \\
\hline 兽鄫总 & $\begin{array}{l}* \\
0 \\
0 \\
0 \\
0 \\
- \\
\end{array}$ & 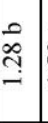 & $\begin{array}{l}0 \\
\vdots \\
\vdots\end{array}$ & \begin{tabular}{|l}
$\infty$ \\
$\infty$ \\
$\infty$ \\
$\infty$ \\
0 \\
0
\end{tabular} \\
\hline 茞吉哥 & 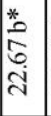 & $\begin{array}{l}\overrightarrow{2} \\
\vec{i} \\
\text { ते }\end{array}$ & & 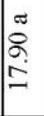 \\
\hline 害总离 & 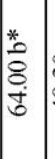 & $\begin{array}{ll}\pi \\
0 \\
0 \\
\infty \\
\infty \\
\sigma\end{array}$ & & 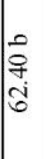 \\
\hline 咅 & 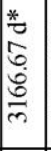 & 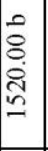 & 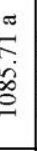 & 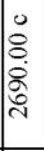 \\
\hline 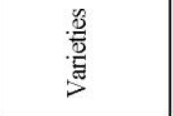 & . & $\bar{\exists}$ & |" & 跑 \\
\hline
\end{tabular}

\begin{tabular}{|c|c|c|c|}
\hline 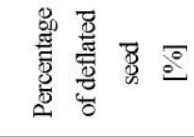 & 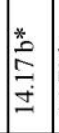 & & 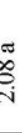 \\
\hline 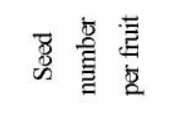 & 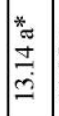 & 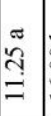 & : \\
\hline 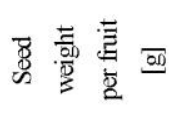 & 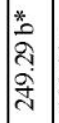 & 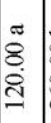 & : \\
\hline 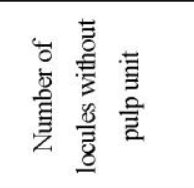 & $\mid$ & : & 8 \\
\hline 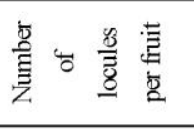 & \begin{tabular}{|c|} 
\\
$\vdots$ \\
8 \\
\hdashline \\
\end{tabular} & 8 & $\overbrace{i}$ \\
\hline 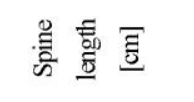 & $\mid$ & $\cong$ & F. \\
\hline 蛋 总 & 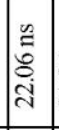 & 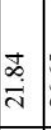 & 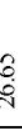 \\
\hline 昰兽总总 & $\cong$ & $\sqrt{n}$ & $\stackrel{\overbrace{}}{:}$ \\
\hline 党兽总 & 草 & 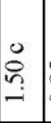 & б. \\
\hline 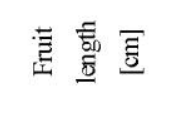 & 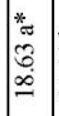 & 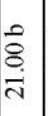 & तै \\
\hline 意总总 & 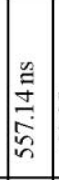 & 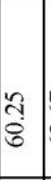 & \\
\hline 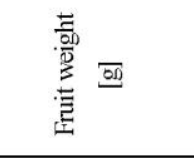 & 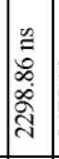 & 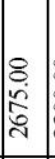 & \\
\hline 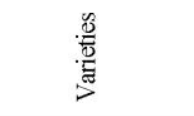 & 吅 & $\mid$ & \\
\hline
\end{tabular}


weight per fruit, seeds number per fruit, and percentage of deflated seed. Different results were obtained by Lim and Luders (2009) in the crossing of durian varieties in which 'Gumpun B', 'Yaow Gaan B' and 'Gob B' were used as maternal parents. The influence of the maternal parent manifested itself only in the spine length. On the crosspollination of cherimoya, seeds number was affected by the maternal parent (Kahn et al., 2003). Among the four maternal parents used, 'Matahari' produced the largest fruit with the thickest flesh, the highest percentage of edible portion and all locules were filled.

The paternal parent (metaxenia) affected several characters of fruit such as fruit length and rind thickness, while the phenomenon of xenia was apparent in the number of seeds, seed weight per fruit, and percentage of deflated seed (Tab. 5). Similar results were obtained in the crosspollination of durian flowers where the paternal parent influenced fruit length, fruit weight, number of locules with pulp unit, rind weight, number of pulp unit, number of wellformed pulp unit, seeds number and seed weight (Lim and Lauders, 2009). The effect of the paternal parent occurs on fruit length, seed weight per fruit and seeds number per fruit on the crossings of cherimoya (Kahn et al., 2003). Similarly, the influence of the paternal parent manifested itself in the size of fruit (diameter, height and weight) in the cross-pollination of apple (Bodor et al., 2008).

The quality of durian fruit that is preferred by consumers should have criteria such as medium size (1.6-
$2.5 \mathrm{~kg} /$ fruit), sweet taste, fluffy texture, thick flesh and small seeds (Santoso et al., 2008). Cross-pollination with Sitokong as the paternal parent produced the smallest seed weight per fruit and seeds number per fruit, but higher percentage of deflated seed than the crossing with 'Lai'.

\section{CONCLUSIONS}

1. The percentage of fruit set was $0 \%$ to $20 \%$ for the various crossing combinations. Crossing of Matahari x Sitokong produced the highest percentage of fruit set, which was $20 \%$.

2. The maternal effect occurs on fruit set, fruit weight, circumference of the fruit, fruit length, fruit rind thickness, flesh thickness, edible portion, spine length, number of locules without pulp unit, seed weight per fruit, seeds number per fruit, and percentage of deflated seed characters. 'Matahari' variety as maternal parent had the largest fruit with the thickest flesh, the highest percentage of edible portion and all locules were filled.

3. The paternal effect occurs on the percentage of fruit set, fruit length, rind thickness, number of seeds per fruit, seed weight per fruit, and percentage of deflated seed. The variety 'Sitokong' as paternal parent had the lowest seed weight per fruit, seeds number per fruit and the highest percentage of deflated seed. The results of this research are expected to be adopted by durian farmers to determine the combination of varieties which could be planted. 
Acknowledgements: We wish to thank: Sukarmin, Farihul Ihsan and Warya for valuable assistance during the study. This study was funded by the DIPA of ITFRI fiscal year 2010 and 2011.

\section{REFERENCES}

Bodor P., Gaál M., Tóth M. 2008. Metaxenia in apples cv. 'Rewena', 'Relinda', 'Baujade' as influenced by scab resistant pollinizers. INTER. J. HORT. SCI. 14 (3): 11-14.

Bumrungsri S., Sripaoraya E., Chongsiri T., Sridith K., Racey P.A. 2009. The pollination ecology of durian (Durio zibethinus, Bombacaceae) in southern Thailand. J. TROPICAL ECOLOGY. 25: 85-92.

Gupton C.L., Spiers J.M. 1994. Interspecific and Intraspecific Pollination Effects in Rabbiteye and Southern Highbush Blueberry. HORT SCI. 29(4): 324-326.

Honsho C., Yonemori K., Somsri S., Subhadrabandhu S., Sugiura A. 2004. Marked improvement of fruit set in Thai durian by artificial cross-pollination. HORT SCI. 101: 339-406.

Kahn T.L., Adams C.J., Arpaia M.L. 2003. Paternal and maternal effects on fruit and seed characteristics in cherimoya (Annona cherimola Mill.). SCI. HORTIC. 59(1): 11-25.

Lim T.K., Luders L. 1998. Durian flow- ering, pollination and incompatibility studies. ANNALS APPL. BIOL. 132: 151-165.

Lim T.K., Luders L. 2009. Boosting Durian Productivity. Rural Industries Research and Development Corporation. Darwin, $124 \mathrm{p}$.

Lo K.H., Chen I.Z., Chang T. L. 2007. Pollen-tube growth behaviour in 'Chanee' and 'Monthong' durians (Durio zibethinus L.) after selfing and reciprocal crossing. J. HORT. SCI. BIOTECH. 82(6): 824-828.

Mizrahi Y., Mouyal J., Nerd A., Sitrit Y. 2004. Metaxenia in the Vine Cacti Hylocereus polyrhizus and Selenicereus spp. ANNALS BOTANY 93: 469-472.

Olfati J.A., Sheykhtaher Z., Qamgosar R., Khasmakhi-Sabet A., Peyvast Gh., Samizadeh H., Rabiee B. 2010. Xenia and metaxenia on cucumber fruit and seed characteristics. INTER. J. VEGETABLE SCI. 16(3): 243-252.

Santoso P.J., Novaril M., Jawal A.S., Wahyudi T., dan Hasyim A. 2008. Idiotipe Durian Nasional Berdasarkan Preferensi Konsumen. J. HORTIKULTURA 18(4): 395-401.

Shaari A.R., Abidin M.Z., Osman M.S. 1985. Some aspects of pollination and fruit set in durian, Durio zibethinus Murr. cultivar D24. TEKNOLOGI BUAH-BUAHAN. 1(1), p. 1-4. 


\title{
WPŁYW FORM RODZICIELSKICH NA CECHY OWOCÓW DURIANA (Durio zibethinus Murr.) Z ZAPYLEŃ KRZYŻOWYCH
}

\author{
Ni Luh Putu Indriyani, Sri Hadiati, Fitriana Nasution, \\ Edison, Sudjijo i Yulia Irawati
}

\author{
S T R E S Z C Z E N I E
}

Badano wpływ form rodzicielskich na cechy owoców duriana z zapyleń krzyżowych. Odmianami rodzicielskimi użytymi w krzyżowaniach były 'Matahari', 'Kani', 'Otong', 'Sitokong', 'Lai', 'Kim', 'Sunan', 'Bokor', 'Hortimart' i 'Tangkue'. Badania wykazały, że odsetek zawiązywania owoców wynosił od $0 \%$ do $20 \%$ w różnych kombinacjach krzyżowań. Wpływ odmiany jako formy matecznej był istotny na takie cechy, jak zawiązywanie owoców, masę owoców, obwód owocu, długość owocu, grubość skórki owocu, grubość miąższu, udział części jadalnej, długość kolców, liczba komór bez miąższu, całkowita masa i liczba nasion w pełni wykształconych oraz procentowy udział nasion niewypełnionych. Odmiana Matahari użyta jako forma mateczna wytwarzała największe owoce $\mathrm{z}$ najgrubszym miąższem podskórnym, w najwyższym procencie części jadalnych i wszystkimi komorami wypełnionymi. Formy ojcowskie miały wpływ na zawiązywanie owoców, długość owocu, grubość skórki, liczbę nasion, całkowitą wagę nasion oraz udział nasion niewypełnionych. Odmiana Sitokong użyta jako forma ojcowska miała najniższą całkowitą masę nasion i najmniejszą liczbę nasion oraz najwyższy udział nasion niewypełnionych.

Słowa kluczowe: zapylenie krzyżowe, formy rodzicielskie, ksenia, metaksenia, jakość owoców 